\title{
Correction to: Cutting the edge between cancerogenesis and organogenesis of the pancreatic endocrine lineage allocation-comprehensive review of the genes Synaptotagmin 13 and 533041C22 Rik in epithelial-to-mesenchymal transition
}

\author{
Stefanie Julia Willmann ${ }^{1,2}$
}

(c) Springer Science+Business Media, LLC, part of Springer Nature 2021

A Correction to this paper has been published: https://doi.org/10.1007/s10555-021-09978-y

\section{Correction to: Cancer and Metastasis Reviews (2021)}

\section{9:953-958}

\section{https://doi.org/10.1007/s10555-020-09897-4}

The article Cutting the edge between cancerogenesis and organogenesis of the pancreatic endocrine lineage allocation-comprehensive review of the genes Synaptotagmin 13 and 533041C22 Rik in epithelial-to-mesenchymal transition, written by Stefanie Julia Willmann, was originally published Online First without Open Access. After publication in volume 39, issue 3, page 953-958 the author decided to opt for Open Choice and to make the article an Open Access publication. Therefore, the copyright of the article has been changed to (c) The Author(s) 2020, and the article is forthwith distributed under the terms of the Creative Commons Attribution 4.0 International License, which permits use, sharing, adaptation, distribution, and reproduction in any medium or format, as long as you give appropriate credit to the original author(s) and the source, provide a link to the Creative Commons licence, and indicate if changes were made. The images or other third party material in this article are included in the article's Creative Commons licence, unless indicated otherwise in a credit line to the material. If material is not included in the article's Creative Commons licence and your intended use is not permitted by statutory regulation or exceeds the permitted use, you will need to obtain permission directly from the copyright holder. To

The original article can be found online at https://doi.org/10.1007/ s10555-020-09897-4.

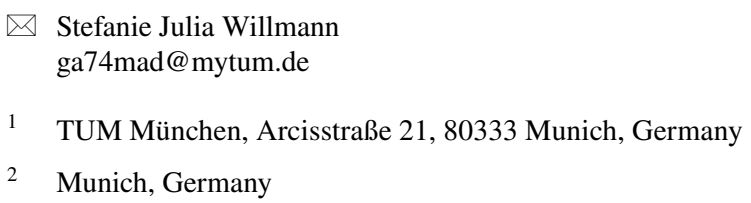

view a copy of this licence, visit http://creativecommons. org/licenses/by/4.0. Open Access funding enabled and organized by Projekt DEAL.

The original article has been corrected. 